\title{
Aqueous Two-Phase Extraction Advances for Bioseparation
}

\section{Arafat M Goja ${ }^{1,2}$, Hong Yang ${ }^{1,3,4,5 *}$, Min Cui ${ }^{6,7}$, Charles $\mathrm{Li}^{8}$}

${ }^{1}$ College of Food Science and Technology, Huazhong Agricultural University, Wuhan, Hubei 430070, China

${ }^{2}$ Department of Food Science and Technology, Faculty of Agriculture and Natural Resources, Bakht Alruda University, ED Dueim, 1311, Sudan

${ }^{3}$ Key Laboratory of Environment Correlative Dietology, Huazhong Agricultural University, Ministry of Education, Wuhan, Hubei 430070, China

${ }^{4}$ National R\&D Branch Center for Conventional Freshwater Fish Processing (Wuhan), Wuhan, Hubei 430070, China

${ }^{5}$ Aquatic Product Engineering and Technology Research Center of Hubei Province, Wuhan, Hubei 430070, China

${ }^{6}$ State Key Laboratory of Agricultural Microbiology, Huazhong Agricultural University, Wuhan, Hubei 430070, China

${ }^{7}$ Laboratory of Animal Virology, College of Veterinary Medicine, Huazhong Agricultural University, Wuhan, Hubei 430070, China

${ }^{8}$ College of Food Science, Fujian Agricultural and Forestry University, Fuzhou, China

\begin{abstract}
Aqueous two-phase extraction (ATPE), unique liquid-liquid extraction, involves a transfer of solute from one aqueous phase to another. ATPE includes polymer-polymer type and polymer-salt type systems for the recovery of proteins. The protein must be recovered in a highly purified form in order to improve its quality, decrease energy consumption, reduce waste and minimize costs. To acquire the high value and achieve good control over processes, the reliable, multi-component products are required especially those with the ability to investigate complex processing conditions. The current reviewing paper discusses the most recent progresses for the recovery of biomolecules by using the ATPE, covering the mechanism, which controls the phase formation and the behavior of solute partitioning in aqueous twophase systems (ATPS) processes. The review discusses also the increasing application for the recovery of high-value bioproducts, the recent development of alternative low cost ATPS and disadvantages attributed to ATPS.
\end{abstract}

Keywords: Aqueous Two-Phase Extraction; Protein; Bioseparation

\section{Introduction}

Aqueous two-phase extraction (ATPE) system is composed of either two different immiscible mixing polymers, or one polymer with salt, which are water-soluble in a certain concentration [1,2]. It has been well known as a useful technique for separation and purification of biomolecules, such as proteins [3-14] and antibodies [15-17]. Partitioning of biomolecules in ATPE systems is affected by many factors, including molecular weight/size of polymer and concentration of polymer. Also, the ionic strength of salt and the addition of salts, such as $\mathrm{NaCl}$, improve the hydrophobic resolution of the system. Furthermore, the partitioning of biomolecules can also be influenced by the degree of $\mathrm{pH}$ and affinity of the macromolecule for the phaseforming polymer [1,18-21].

The conventional liquid-liquid extraction using organic-aqueous phase systems was previously established. However, due to the poor solubility and possible denaturation of the protein in organic solvents, the technique leads to limit their application in partitioning of many bimolecular products [22]. Now, the application of liquid-liquid extraction based on aqueous two-phase systems (ATPS) has been increased. The recoveries of high-value biomolecules were achieved from various plants using different applications, such as papain from Papaya fruit [23], $\alpha$ - and $\beta$-amylases from Zea mays malt [9], glutenin flour from special wheat [24] and recombinant protein from alfalfa [25]. In addition, the high-value bioproducts also are obtained from different fruits, such as bromelain (EC 3.4.22.33) from pineapple [26], serine protease from Mango [12], invertase from tomato [11] and papain from Papaya fruit [23]. In recent years, the high-quality biomolecules have been recovered from various sources, such as theanine from waste liquid of tea [27] and flavonoids from pigeon pea roots [28]. There are also other bioproducts, such as recombinant human serum albumin from Pichia pastoris broths [29], luciferase from fireflies [30] and immunoglobulin G [17,31].

The ATPE has some advantages in the downstream processing of biomolecules, for instance, the system characterized with high-water content $(70-80 \%, \mathrm{w} / \mathrm{w})$ and low interfacial tension between conjugated phases. This, in fact, provides a secure separation and purification technique for biomolecules $[1,32,33]$. In addition, it decreases energy consumption, reduces waste and minimizes costs due to a few steps of unit operation, which require low-energy input and easy to scale up. The ATPE also increases biomolecules recovered in a highly purified form. Moreover, it can be used in combination of other separation methods such as liquid chromatography [1,34], packed column [17], magnetic particle adsorption [35].

The ATPE in downstream processing of biomolecules in the bench-scale prototype has been successful with potentially commercial application. However, the scale-up of the ATPS of some biological products were not achieved [15]. Most of those methods have some limitations such as low capacity, several steps and fewer chemicals and proteolytic stability, which may lead to the contamination of the final product $[36,16]$. Moreover, there are maybe some difficulties during the large scale-up of the ATPS in the industry, especially polyethylene glycol (PEG)/salt system causing corrosion of equipment and precipitation of target product. Thus, the development of alternative methods is very important to achieve the desired biomolecules in high quality and purity. The objective of this paper reviews recent progresses for the recovery of biological products by using the ATPE and the factors affecting partitioning in ATPS processes. The paper also reviews

*Corresponding author: Hong Yang, College of Food Science and Technology, Huazhong Agricultural University, Wuhan, Hube 430070, China, Tel: 86-27-87671045; Fax: 86-27-87278373; Email: yangh@mail.hzau.edu.cn.

Received November 07, 2013; Accepted November 25, 2013; Published December 05, 2013

Citation: Goja AM, Yang H, Cui M, Li C (2013) Aqueous Two-Phase Extraction Advances for Bioseparation. J Bioprocess Biotech 4: 140 doi: 10.4172/2155-9821.1000140

Copyright: ( 2013 Goja AM, et al. This is an open-access article distributed under the terms of the Creative Commons Attribution License, which permits unrestricted use, distribution, and reproduction in any medium, provided the original author and source are credited. 
the modern development of the alternative low cost ATPS, and some disadvantages associated with the ATPS.

\section{Separation and Purification of Bioproducts by the Atpe System}

The ATPS is considered a powerful and versatile technique, having low-cost and good efficiency downstream process, A high-water content $(>70 \%(\mathrm{w} / \mathrm{w})$ water) generates low interfacial tension, nonflammable, slightly toxic and safe to the environment. This system has high selectivity and recovery yield of biomolecules [37,38]. It has been widely used in the field of biotechnology for separation and purification of various biological products, such as proteins, amino acids, enzymes, cells, antibodies and other bioproducts $[1,7,39,40]$. Also the ATPS method has received a special application in the area of non-biotechnology, including the recovery of glycosaminoglycans from tannery wastewater [41], crocins from saffron stigmas [42], papaverin from pericarpium papaveris [43].

Protein is one of the most important bio-molecules in the living organism, which is responsible for many reactions and functionalities, such as metabolism, bioprocess, signal transduction, cellular and extracellular structures [44]. A protein in a purified form would be very useful in the applications (e.g. food, chemical and pharmaceuticals). The challenging problem is that the downstream processing mostly accounts for $50-80 \%$ of the total production costs of proteins [45]. Conventional methods for separation and purification of proteins usually are expensive, time-consuming and difficult to scale up $[44,46]$. The good news is that the ATPE, an achievable alternative method, has been recognized as an economical and effective technique for recovery and purification of proteins with a variety of advantages, such as simple, fast, low-cost and easily scaled-up. These make it possible strategy for purification of a desired protein in large-scale [35,47]. Partitioning of proteins in the ATPS depends on many factors, namely, hydrophobicity, molecular size, weight and conformation, net electrical charge and environmental conditions [48-50]. A protein purified by this method will be considered to be very important bimolecular product for the bioprocess as it can be used in commercial scale at low cost with relative reliability and accessibility. Optimizing conditions of some selected examples of bioproducts (proteins, enzymes and other products) are summarized in Tables 1-3, respectively.

\section{Mechanism Controlling Phase Formation and the Behavior Solute Partitioning in the Atps Processes}

Partitioning of biomolecules in the ATPS is decided by main electrostatic, hydrophobic and steric hindrance interactions that are very important to the ATPS composition. The ATPS made up by the polymer and the nonionic surfactant results in hydrophobic interaction, [8]. Although electrostatic interactions and salting-out effects during protein extraction in ionic liquid-based aqueous two-phase extraction are important for the transfer of the proteins, the thermodynamics of hydrophobic interactions plays the most important role as a main driving force [44].

Generally, the partitioning of biological products is a result of Van der Waals and ionic interactions of biomolecules with the surrounding phase [37]. However, it is still not well understood the responsible mechanism for the partitioning of biomolecules in the ATPS, which is very important for developing the reliable technique for the industrial application. Therefore, the factors influencing the partitioning of biomolecules are a useful way to study the behavior of solute partitioning in the ATPS process.

\section{Factors Influencing Partitioning of Biomolecules in the Atps}

\section{Impact of polyethylene glycol (PEG) characteristics}

The PEG characteristics, including weight, size and concentration, are very important factors in the properties of the phase-forming system [51]. The influences of these factors on the partitioning of biomolecules have been reported previously $[11,33,41,52]$.

Molecular weight and size: The partitioning of biomolecules depends on the molecular weight of polymers and the other components constituting the phase. Molecular weight has a strong effect on the partitioning behavior of biomolecules [11,12,53]. Higher molecular weight of PEG has less coefficient factor and then lower polymer concentration needed for high separation [38]. The low molecular weight of PEG has a hydrophilic end group with shorter polymer chains that reduces the hydrophobicity [41], while better partitioning can be achieved due to the low interfacial tension of low molecular weight. An increase in the PEG molecular mass reduces free volume by increasing the chain length of the PEG polymer [11,25,30], resulting in partitioning of the biomolecules to the bottom phase [4]. The increase in polymer weight causes the reduction of free volume of the top phase, so the partition of biomolecules in the salt-rich bottom phase decreases the partitioning coefficient [54].

Another study indicated the influence of different molecular weights of PEG $(4,000,6,000$, and 8,000$)$ on partitioning of myoglobin and

\begin{tabular}{|c|c|c|c|c|c|c|c|}
\hline Bioproduct & Source & System and Composition (\%w/w) & $\mathrm{K}_{\mathrm{p}}$ & Yield (\%) & TLL (\%w/w) & $\mathrm{pH}$ & Reference \\
\hline Protein & Cheese whey & PEG6000/potassium phosphate $(11.7 / 10 \%)$ & 0.9 & 83.4 & 23.9 & 7.0 & [67] \\
\hline Glutenin & Wheat flour & PEG1500/Li ${ }_{2} \mathrm{SO}_{4}(14.0 / 13.23 \%)$ & 5.90 & 84.9 & 35.51 & - & [24] \\
\hline Recombinant protein & Alfalfa & $\begin{array}{c}\text { PEG8000/phosphate } \\
(16.1 / 10.0 \%)\end{array}$ & 0.1 & 88 & 35.7 & 7.0 & [25] \\
\hline$(\alpha-l a),(\beta-l g)$ and $(\mathrm{Gmp})$ & Milk whey & $\begin{array}{c}\text { PEG2000/phosphate } \\
(13.0 / 13.0 \%)\end{array}$ & $\begin{array}{l}0.48 \\
0.01 \\
0.92\end{array}$ & $\begin{array}{l}81.1 \\
97.3 \\
97.8\end{array}$ & - & 6.7 & [6] \\
\hline OVA & Chicken egg & PEG4000/poly(acrylic acid) (PAA) + $1 \mathrm{M} \mathrm{NaCl}$ & 5.5 & 87.4 & 54.7 & 8.0 & {$[37]$} \\
\hline Protein & Zea mays malt & PEG $6000 / \mathrm{CaCl}_{2}$ & 4.2 & - & - & 7.0 & [39] \\
\hline Bromelain & Pineapple Peel & $\begin{array}{c}\text { PEG3000/MgSO } \\
(15 / 20 \%)\end{array}$ & 2.93 & 108.45 & - & 9.0 & [71] \\
\hline$(\alpha-A l)$ & Wheat flour & PEG2000/(FBP) trisodiumsalt (11.7/19\%) & - & 79 & - & 7.0 & [69] \\
\hline Protein & Corn & $\mathrm{PEG} 1450 / \mathrm{Na}_{2} \mathrm{SO}_{4}-8.5 \% \mathrm{NaCl}$ & - & 93 & - & 7.0 & [5] \\
\hline
\end{tabular}

$\mathrm{Kp}=$ partition coefficient of protein, TLL= Tie line length, $(-)=$ the value was not given, $\alpha-\operatorname{la}=\alpha-$ lactalbumin, $\beta$-lg= $\beta$-lactoglobulin, $\mathrm{Gmp}=$ glycomacropeptide, $\alpha-A \mathrm{I}=$ a-amylase inhibitor, FBP= fructose-1,6-bisphosphate, OVA= Ovalbumin

Table 1: Optimizing partitioning of proteins in the various ATPS recovered from foods. 
Citation: Goja AM, Yang H, Cui M, Li C (2013) Aqueous Two-Phase Extraction Advances for Bioseparation. J Bioprocess Biotech 4: 140 doi: 10.4172/2155-9821.1000140

Page 3 of 8

\begin{tabular}{|c|c|c|c|c|c|c|c|}
\hline Bioproduct & Source & System and Composition (\%w/w) & Kp & Yield\% & TLL\% & pH & Reference \\
\hline Serine Protease & Mango Peel & $\begin{array}{c}\text { PEG8000/ phosphate } \\
(-/ 4.5 \%)\end{array}$ & 84.2 & 97.3 & 17.2 & 7.5 & [12] \\
\hline Inverts & Tomato & $\begin{array}{l}\mathrm{PEG} 3000 / \mathrm{Na}_{2} \mathrm{SO}_{4} \\
(15 / 12 \%)+5 \% \mathrm{KCl}\end{array}$ & 1.1 & 90 & - & 4.5 & [11] \\
\hline Serine Protease & $\begin{array}{c}\text { Kesinai (Streblus } \\
\text { asper) }\end{array}$ & $\begin{array}{c}\text { PEG6000/rich- } \mathrm{MgSO}_{4} \\
(16 / 15 \%)\end{array}$ & - & 96.7 & - & 7.0 & [59] \\
\hline Papain & Papaya & $\begin{array}{c}\mathrm{PEG} 6000 /\left(\mathrm{NH}_{4}\right)_{2} \mathrm{SO}_{4} \\
(8 / 15 \%)\end{array}$ & - & 89.9 & - & 5.0 & [23] \\
\hline Phytase & Aspergillus niger & $\begin{array}{l}\text { PEG6000+8000/ Citrate } \\
(10.5 / 20.5 \%)\end{array}$ & 0.96 & 96.0 & - & 5.6 & [13] \\
\hline Protease & $\begin{array}{l}\text { Tuna (Thunnus } \\
\text { alalunga) }\end{array}$ & $\mathrm{PEG} 2000 / \mathrm{MgSO}_{4}(15 / 15 \%)$ & 0.86 & 89.1 & - & - & Nalinanon et al. \\
\hline Soybean peroxidase & Soybean & $\begin{array}{c}\text { PEG4000-IDA- } \mathrm{Cu}^{2+} / \mathrm{Na}_{2} \mathrm{SO}_{4} \\
(4 / 10 \%)\end{array}$ & 0.05 & 64 & - & - & [72] \\
\hline G6PDH & $\begin{array}{l}\text { Sigma } \\
\text { (USA) }\end{array}$ & $\begin{array}{l}\text { PEG)/phosphate } \\
\text { buffer(17.5/ } 15 \%)\end{array}$ & 351 & 97.7 & - & 7.5 & [55] \\
\hline$\beta$-gala.; $\beta$-gluc. & Barley & $\begin{array}{c}\text { PEG1500/ }\left(\mathrm{NH}_{4}\right)_{2} \mathrm{SO}_{4} \\
(14 / 13 \%)\end{array}$ & $2.7 ; 2.8$ & $\begin{array}{l}98.26 \\
92.58\end{array}$ & 19.65 & $\begin{array}{l}6.9 \\
6.5\end{array}$ & [53] \\
\hline Lipase (E.C. 3.1.1.3) & $\begin{array}{l}\text { Burkholderia } \\
\text { pseudomallei }\end{array}$ & 2-propanol/phosphate (ATPS) (16/4.5\%) & 13.5 & 99 & - & 9.0 & [40] \\
\hline PPL & Sigma (USA) & PEG1500/potassium phosphate (17/13\%) & 12.7 & 94.7 & - & 7.0 & [14] \\
\hline PheDH & $\begin{array}{l}\text { Bacillus sphaeri- } \\
\text { cus }\end{array}$ & PEG-6000/( $\left.\mathrm{NH}_{4}\right)_{2} \mathrm{SO}_{4}(8.5 / 17.5 \%)$ & 0.027 & 94.42 & 39.89 & 8.0 & [56] \\
\hline Invertase & Baker's yeast & PEG3000/MgSO ${ }_{4}(15 / 123 \%)+5 \% \mathrm{MnCl}_{2}$ & - & 98 & - & 5.5 & [54] \\
\hline Plant-esterase & Wheat flour & $\begin{array}{c}\mathrm{PEG} 1000 / \mathrm{NaH}_{2} \mathrm{PO}_{4}(27.0 / 13.0 \%) \text { and PEG1000/ } \\
\quad \mathrm{NaH}_{2} \mathrm{PO}_{4} /\left(\mathrm{NH}_{4}\right)_{2} \mathrm{SO}_{4}(27.0 / 13.0 / 6.0 \%)\end{array}$ & - & 83.16 & - & 5.0 & [62] \\
\hline
\end{tabular}

$\mathrm{Kp}=$ partition coefficient of protein, TLL= Tie line length, IDA= Iminodiacetic acid, G6PDH= Glucose-6-phosphate dehydrogenase, pk= purification factors, $\beta$-gala $=\beta$-galactosidase,$\beta$-glu $=\beta$-glucosidase, $\mathrm{PheDH}=$ phenylalanine dehydrogenase, $\mathrm{PPL}=$ porcine pancreatic lipase, $(-)=$ the value was not given

Table 2: Optimizing partitioning of different enzymes recovered in the various ATPS.

\begin{tabular}{|c|c|c|c|c|c|c|c|}
\hline Bioproduct & Source & System and composition (\%w/w) & Kp & Yield (\%) & TLL (\%) & $\mathrm{pH}$ & Reference \\
\hline $\lg G$ & $\begin{array}{l}\text { Chinese Hamster } \\
\text { Ovary }(\mathrm{CHO})\end{array}$ & PEG3350/phosphate-rich phase (cont, ATPE) & - & 85 & - & 6.0 & [98] \\
\hline Lectin & Canavalia grandiflora Benth & PEG400/sodium citrate (20/20\%) & 8.67 & 104 & - & 6.0 & Porto et al. \\
\hline Lutein & $\begin{array}{l}\text { Green microalga (Chlorella } \\
\text { protothecoides) }\end{array}$ & PEG 8000/phosphate (22.9/10.3\%) & - & 81.0 & 49.4 & 7.0 & Cisneros et al. \\
\hline Luciferase & Fireflies (Photinus pyralis) & PEG1500 rich $\left(\mathrm{NH}_{4}\right)_{2} \mathrm{SO}_{4}(4 / 20.5 \%)$ & - & $\begin{array}{l}13.69 \text { fold } \\
\text { in pk }\end{array}$ & - & - & [30] \\
\hline Crocins & $\begin{array}{c}\text { Saffron stigmas (Crocus } \\
\text { sativus) }\end{array}$ & $\begin{array}{l}\text { Ethanol/ potassium phosphate }(19.8 / 16.5 \%)+0.1 \\
\qquad \mathrm{M} \mathrm{NaCl}\end{array}$ & - & $>75$ & 25 & - & [42] \\
\hline Glycosaminoglycans & Tannery wastewater & PEG4000/(PAA) & - & 91.50 & 54.7 & 8.0 & [41] \\
\hline
\end{tabular}

$\mathrm{Kp}=$ partition coefficient of protein, $\mathrm{TLL}=$ Tie line length, $(-)=$ the value was not given, IgG=Human immunoglobulin $\mathrm{G}$

Table 3: Optimizing partitioning of some selected products in the various ATPS recovered from different sources.

ovalbumin, the partitioning of both proteins is higher if the molecular mass of PEG is lower [37]. In PEG (4,000)-phenylacetic acid (PAA) system, the percentage yields of extracted myoglobin at $20 \mathrm{oC}$ and $\mathrm{pH}$ 8.0 in $1 \mathrm{M} \mathrm{NaCl}$ increases from $75.2 \%$ to $95.2 \%$ with the increase of tie line length (TLL). This is due to the increase of hydrophobicity and partitioning coefficient of the ATPS. It also affects the partitioning of proteins present in the phase system, whereas in the case of ovalbumin, the increase is from $67 \%$ to $87.4 \%$. Different molecular weights of PEG $(1,000,2,000,3,000,4,000,6,000$ and 8,000$)$ have been used to purify invertase enzyme from tomato, while the partitioning of invertase in PEG-Na2SO4 system is strongly dependents on the molecular weight of the PEG [11]. Nearly all invertases partitioned into the top phase with PEG-3,000, while most contaminating proteins were partitioned into the lower phase in the ATPS containing the other PEGs $(1,000$, $2,000,4,000,6,000$ and 8,000 ). A wide range of molecular weight PEG $(400,1000,1,500,4,000,6,000$ and 8,000) was screened for differential partitioning of $\alpha$-galactosidase and $\beta$-glucosidase from the barley [53]. For low molecular weight PEG, both the enzymes partitioned to top phase whereas for high molecular weight PEG, both the enzymes partitioned to bottom phase. PEG 1,500 had better partitioning of both of enzymes. The highest partitioning (97.22\%) of luciferase enzyme from fireflies (Photinus pyralis) was obtained in 1,500PEG/(NH4) ${ }_{2} \mathrm{SO}_{4}$ system [30]. In the smaller molecular mass PEG (300, 400 and 600), there was a tendency for glucose-6-phosphate dehydrogenase (G6PDH) to stay in the top phase (PEG phase) [55]. In the higher value of PEG $(1,000$ and 1,500), the larger amount of G6PDH stayed in the bottom phase. However, the low molecular mass PEG is also unsuitable for adequate partitioning, due to the decrease of the exclusion effect [56]. It allows the polymer to attract all the proteins to the upper phase. Thus, the choice of the most suitable intermediate molecular mass of PEG is very important for increasing the extraction efficiency of the ATPE system $[54,57,58]$. 
PEG concentration: Several studies demonstrated the influence of different PEG concentrations $(7-21 \%, w / w)$ on protein partition coefficient $\left(\mathrm{K}_{\mathrm{p}}\right)$ and enzyme partition coefficient $\left(\mathrm{K}_{\mathrm{E}}\right)$ from various sources $[53,54,59]$. Their results showed the significant effect of the PEG concentration on the partitioning of biomolecules in the ATPS. The highest concentration in PEG lowered $\mathrm{K}_{\mathrm{P}}$ and $\mathrm{K}_{\mathrm{E}}$. The intermediate concentration of PEG/salt is more applicable for good separation and purification. When serine protease was extracted from Kesinai (Streblus asper) leaves, the $\mathrm{K}_{\mathrm{E}}$ of the enzyme decreased significantly at a low concentration of molecular weight $(8 \%$ PEG4,000) [59]. On the other hand, the high PEG concentration and high molecular weight gave negative effect on the partition coefficient of the enzyme. In partitioning of a yeast invertase at different PEG-3,000 concentrations $(7.5-20 \%, \mathrm{w} / \mathrm{w})$ together with $20 \%(\mathrm{w} / \mathrm{w}) \mathrm{MgSO}_{4}$ at $\mathrm{pH} 5.0$, partitioning of invertase in the ATPS is affected significantly by the PEG concentration [54]. The PEG at concentration of $15 \%(\mathrm{w} / \mathrm{w})$ resulted in the highest value (3.2-fold) of purification factors (PF) with the yield of $134 \%$. At concentration of $20 \%(\mathrm{w} / \mathrm{w})$, purification factors and yield decreased dramatically to 2.1 -fold and $46 \%$, respectively. Similarly, high purification factors and yield were obtained when invertase was partitioned in a $15 \%(\mathrm{w} / \mathrm{w}) \mathrm{PEG} / 12.5 \%(\mathrm{w} / \mathrm{w}) \mathrm{Na}_{2} \mathrm{SO}_{4}$ at $\mathrm{pH} 5.0$ [11].

\section{Impact of salt concentration}

The impact of salt concentration has been widely studied. Increases in salt concentration result in an increase in partition coefficients of bioproducts in upper phase or interface due to salting out $[11,53,60]$. In general, proteins with the negative charge tend to partition to the top phase in PEG/salt systems while those with the positive charge usually go to the bottom phase $[54,61,62]$.

Varied salt concentrations have been used in separation of proteins (cytochrome c, lysozyme, trypsin, bovine serum albumin and myoglobin) by the ATPE system combined with high-performance liquid chromatography (HPLC) [34]. When (NH4) $)_{2} \mathrm{SO}_{4}$ concentration increased from $10 \%$ to $18 \%$, the top phase volume decreased and the bottom phase volume increased. All proteins retained in the lower phase except lysozyme, which was partitioned in the two phases. Moreover, 23\% (w/w) $\mathrm{MgSO}_{4}$ caused the best partition behavior of a yeast invertase at different concentrations $(15-25 \%$, w/w) in the $\mathrm{PEG} / \mathrm{MgSO}_{4}$ aqueous [54]. Besides the salt type, the distribution of invertase is mainly controlled by concentration of the salt. The partition coefficient $\left(\mathrm{K}_{\mathrm{E}}\right)$ of luciferase increased rapidly as compared to that of total protein $\left(\mathrm{K}_{\mathrm{p}}\right)$ with an increase in salt concentration from $12 \%$ to $16 \%$ [30]. The optimum condition for cephalexin antibody separation was at a concentration of $20 \%$ for both PEG and $\mathrm{Na}_{2} \mathrm{SO}_{4}$ [60]. Similar finding was reported in the case of penicillin $G$ and PAA extraction (phenylacetic acid) in the $\mathrm{PEG} / \mathrm{Na}_{2} \mathrm{SO}_{4}$ ATPS at $\mathrm{pH} 8.0$ [60]. The optimized salt concentration for purification of lipase enzyme was $18 \%$ potassium phosphate with $20 \%$ PEG at the level of $8,000 \mathrm{~g} / \mathrm{mol}$ [63].

\section{Impact of the type of salts}

The selection of salts for the ATPS depends on their ability to promote hydrophobic interactions between biomolecules [64]. The PEG/phosphate system is widely used for recovery of bioproducts [65]. Other salts having similar properties to phosphate, such as sulphate and citrate, have been also used. The changes of the environmental phase system, due to use of different salts, lead to change the behaviors of partitioned protein [62]. Anions are the most effective in partitioning $\left(\mathrm{SO}_{4}^{-2}>\mathrm{HPO}_{4}^{-2}>\right.$ acetate) than cations $\left(\mathrm{NH}_{4}^{+}>\mathrm{K}>\mathrm{Na}^{+}>\mathrm{Mg}^{2+}>\mathrm{Ca}^{2+}\right)$ [66]. Recently, use of salts, like citrate (biodegradable) and ammonium carbonate (volatile) are favored because of their high selectivity, less pollution, biocompatibility and easy to scale-up $[38,50]$. The partition coefficient values of methionine in systems containing $\mathrm{Na}_{3} \mathrm{PO}_{4}$ are greater than values in systems containing $\mathrm{NaH}_{2} \mathrm{PO}_{4}$ or $\mathrm{Na}_{2} \mathrm{HPO}_{4}$ because of more abilities of $\mathrm{Na}_{3} \mathrm{PO}_{4}$ to enhance hydrophobic interactions between particles [7]. The PEG 6,000/potassium phosphate system of $23.9 \%(\mathrm{w} / \mathrm{w})$ TLL gave the best partitioning results with the highest recovery of proteins from cheese whey than the PEG/ammonium sulphate and PEG/potassium dihydrogen phosphate systems [67]. In fact, a significant aggregation tendency of proteins was observed in PEG/ammonium sulphate and PEG/potassium dihydrogen phosphate systems, whose $\mathrm{pH}$ was close to isoelectric $\mathrm{pH}$ of whey proteins. The PEG/ammonium sulphate could be the suitable purification phase for differential partitioning of $\beta$-galactosidase and $\beta$-glucosidase rather than other types of salts, such as sodium sulphate, sodium phosphate, potassium phosphate and sodium citrate. This PEG/ammonium sulphate was found to be the best in terms of activity recovery and differential partitioning of both the enzymes [53], while potassium salts have much better effects on partition of lipase than that sodium salts and ammonium salts. This is due to the partition coefficients increased according to the following order: $\mathrm{K}^{+}>\mathrm{Na}^{+}>\mathrm{NH}_{4}^{+}[68]$.

\section{Impact of $\mathrm{pH}$}

Partitioning of proteins and enzymes to the phases in the ATPE system depends on their isoelectric points (pI) [63]. The $\mathrm{pH}$ of the system, however, affects the charge of target protein and ion composition as well as introduces differential partitioning into the two phases [56]. Accordingly, the initial $\mathrm{pH}$ of the system must be above the $\mathrm{pI}$ of target bio-molecules [65]. A pH value above 7 is suitable for the PEG/phosphate system and a pH below 6.5 is compatible with the PEG/sulphate system. Most of the biomolecules, especially proteins and enzymes, are stable at neutral $\mathrm{pH}$ that is favorable condition to conduct the ATP partitioning. At $\mathrm{pH} 7,79 \%$ a-amylase inhibitor was recovered with 3.2 purification factor in $11.7 \%(\mathrm{w} / \mathrm{w})$ PEG-2000 and 19\% (w/w) fructose-1,6-bisphosphate trisodium salt [69]. When the $\mathrm{pH}$ rose from 5.8 to 8.0 , the $\mathrm{K}_{\mathrm{E}}$, yield and recovery of phenylalanine dehydrogenase (pI 5.3) increased, and the optimal values could be obtained at $\mathrm{pH} 8.0$ [56]. However, an increase in $\mathrm{pH}$ of the ATPS (PEG-4000/ $\mathrm{K}_{2} \mathrm{HPO}_{4}$, $12 / 13 \%$ ) from 7.0 to 9.0 reduced the partition coefficient of lipase from 7.94 to 4.45 and activity recovered from 81.1 to $70.6 \%$ [70]. Enzyme stability slightly reduced in the acidic area, but it was dramatically lost at $\mathrm{pH}$ above 9.0 [71]. Generally, the efficacy of the $\mathrm{pH}$ can be either by changing the charge of the solute or by altering the ratio of the charged species presents [37].

\section{Tie line length (TLL)}

Tie line length can affect biomolecule partitioning by hydrophobicity and interfacial tension between phases of the ATPS. The ATPS becomes more hydrophobic with increasing TLL due to reduction of water availability [8]. An increase in the TLL causes an increase in the protein partition coefficient that, in turns, increases the yield of proteins in the top phase due to reduction of the bottom phase [12]. Increasing TLL in the PEG-salt system makes salting-out more effectively, leading to shift of proteins to the top PEG-rich phase [72]. If protein solubility in the PEG phase is insufficient, protein will precipitate at the interface. Solubility and salting-out limits depend on the properties of individual proteins. Therefore, a different response will be expected when a mixture of protein is handled [39]. It was reported that glutenin partitions from wheat flour, an increase in TLL caused an increase in protein transfer to the upper phase in systems formed by PEG-1,500/sulphate salts (lithium or sodium) [24]. However, in terms of systems that composed 
of PEG-4,000/sulphate salts (lithium or sodium), an increase in TLL caused an increase in protein transfer to the lower phase.

\section{Influence of the addition of $\mathrm{NaCl}$}

In general, addition of neutral salts, such as $\mathrm{NaCl}$, to the ATPS results in an increase in the hydrophobic difference due to generation of an electrical potential difference between two phases [5,12,73]. An increase in the hydrophobicity will decrease the amount of bound water, which keeps the final composition of the systems constantly [15]. Furthermore, it increases the ionic strength and enhances the migration of low molecular weight compounds towards the polymerphase, especially in PEG $<4,000$ [65]. However, the addition of high concentration of neutral salts may cause denaturation of proteins existing in the system, thus low concentration range from 0.0 to $1.0 \mathrm{M}$ is preferred. High yield (97.3\%) of serine protease from mango peel was obtained with addition of $4.5 \%$ of $\mathrm{NaCl}$ to the PEG/dextran ATPS [12]. The addition of different concentrations of salt $(0.0-1.0 \mathrm{M})$ increased the partition coefficient of myoglobin and ovalbumin from 4.20 to 15.77 and 2.82 to 5.51, respectively, in the PEG-4,000/PAA system [37]. Similar results were observed with bovine serum albumin (BSA) in the ATPS [74]. In $6 \%(\mathrm{w} / \mathrm{v})$ of $\mathrm{NaCl}$, the purification factor of lipase enzyme increased significantly from 59.93 to 141.65 fold. However, further addition of $\mathrm{NaCl}$ decreased the $\mathrm{K}_{\mathrm{E}}$ of lipase [63].

\section{Recent Process in Atpe, Applications Economic Costs}

The ATPE is a powerful method commonly used for separation and purification of biomolecules, such as proteins, enzymes and antibodies. It is composed either polymer (PEG)-polymer (dextran) or polymer (PEG)-salts. However, the polymer-polymer interaction dominates due to the low solubility of amphiphilic proteins in the PEG-salt, which has a high tendency to aggregate in aqueous solution that may damage fragile proteins [37]. The environmental problems were raised from elevated salt concentration in waste disposal $[4,75]$. Large chemical consumption during the phase-forming [37] will lead to additional cost for the phase recycling in the system. However, the ATPE based on polymer (PEG)-polymer (dextran) is very expensive because of the high cost of some forming phase polymers, such as dextran [37] and ethylene oxide-propylene oxide copolymers [65]. This, in fact, limits the implementation of this system at the large scale.

In recent years, some progress in the ATPE technique has been reported, including some modification introduced to the ATPE system to recover biomolecules in high value, good quality and low cost, providing basic materials for bio-product processes and increasing the application of the non-biotechnology. The alternative polymers used as a substitute for dextran, are generally safe, low-cost and compatible with the system, such as PEG/nonionic surfactant polymers (Triton X-100 and Tween 80) [8] and ionic liquid-based ATPE [42,44]. The dextran polymer also substituted by alcohol/salt ATPE system [42,76], microfluidic aqueous PEG/detergent ATPE system [77] and acid polymer PEG-poly (acrylic acid) system [37,41]. These alternatives reduce the cost and make the process simpler. On the other hand, many studies have demonstrated that the PEG-salts have some advantages such as simple, fast, easy recyclable and low-cost and viscosity $[11,38,65,78]$. Thus, they are also attractive for commercial applications as a rapid and continuous protein separation [11]. Affinity ligands are introduced into the ATPE system as a free ligand that appears to make the process easier [79-81]. The ATPS in a microfluidic platform was designed and tested for mAbs extraction. This system indicated the potential to be an effective tool to accelerate Bioprocessing design and optimization [82].
Currently, the ATPE based either on a PEG/salt system or a polymer/ polymer system has been rarely used in a large scale due to the high cost of the polymers and the difficulty in isolating the extracted biomolecules from the viscous polymer phase by back extraction [29]. To overcome this limitation, there are studies on the ATPE system composed of alcohols or hydrophilic organic solvents and salts. These studies are characterized with low cost of extraction, easy recovery of solvent by evaporation and simple scale-up in the recovery of many products from different sources $[42,76,83-85]$. For example, $\mathrm{K}_{2} \mathrm{HPO}_{4} /$ ethanol is used for partitioning of proteins, such as lysozyme, chymotrypsinogen solution, BSA and partially purified DNA polymerase from Thermus aquaticus [86]. Ethanol/ $\mathrm{K}_{2} \mathrm{HPO}_{4}$ ATPS was combined with hydrophilic interaction chromatography for the isolation and purification of recombinant human serum albumin (rHSA) [29].

In the last few years, some studies focused on the development of excellent polymers forming ATPE for higher recovering. A lot of novel copolymers forming ATPS are synthesized, such as one $\mathrm{pH}$-response copolymer $\mathrm{P}_{\mathrm{ADB}}$ [87], a light-response polymer PNNC [88], lightresponse reversible polymer $\left(\mathrm{P}_{\mathrm{NBAC}}\right)$ and copolymers $\left(\mathrm{P}_{\mathrm{NDBC}}\right)$ [89]. Also other copolymers have been designed, including $\mathrm{pH}$-response polymer $\left(\mathrm{P}_{\mathrm{ADB}}\right)$ and one light-response polymer $\left(\mathrm{P}_{\mathrm{NBC}}\right)$ [90], $\mathrm{pH}$-thermo $\mathrm{pH}$ response polymer $\left(\mathrm{P}_{\mathrm{ADB}}\right)$ and one thermo-response polymer (PNB) [91], pH-response random copolymers $\left(\mathrm{P}_{\mathrm{ADB}}\right.$ and $\left.\mathrm{P}_{\mathrm{ADBA}}\right)$ [92], and copolymer membrane of poly(acrylonitrile-acrylamide-styrene) [93].

In addition, the reverse micelle solvent system is another ATPE that can be used as an alternative technique for protein separation due to its simplicity and feasibility of large-scale sample loading [94]. The reverse micelle solvent system is a very attractive system for protein separation $[95,96]$. Lastly, there is an application of a novel continuous ATPE prototype for the recovery of biomolecules [97]. It was used for recovery of protein and $\alpha$-amylase from soybean, to extract the lowabundant protein from complex mixtures. A continuous ATPE process incorporating three various steps (extraction, back-extraction, and washing) has been introduced with a pump mixer-settler battery. The ATPS process recovered $99 \%$ purity of IgG from a CHO cell supernatant and $100 \%$ of IgG from a PER.C6 [98]. This new process indicates the ability to successfully recover and purify different antibodies. It could overcome some of the limitations encountered using the typical chromatographic processes, besides inherent advantages of scalability, process integration, capability of continuous operation, and economic feasibility.

Generally, the continuous operation increases partition coefficients with higher recovery efficiencies. The processing time is reduced at least three folds, compared to the batch ATPS. Furthermore, it achieves higher enzyme partitions coefficient $\left(\mathrm{K}_{\mathrm{p}}>4\right)$ and a top phase enzyme recovery $(81 \%)$ with the purification factor 40 -fold than a batch system. It is suggested that the continuous ATPE model can be used in an industry field for the recovery of bioproducts.

\section{Disadvantages Attributes to the Atps}

The development and application of the ATPE have some drawbacks due to lack of information about the exact mechanism of partitioning and unpredictable [56]. There are two restrictions to limit the wide application of the ATPE [99]. Firstly, it is difficult to predict exactly the behavior of target proteins in the ATPE system. Secondly, monitoring the characteristics of proteins is the basic requirement for assessment of bioprocesses, which are affected frequently by the presence of high concentrations of polymers or salts. Considerable time is needed to build first recovery process of the experiment, while big 
budget is needed for installation and limited output of the purification units [69]. Experimental design is needed to determine the optimal ATPS system for partitioning of desired products [65]. Compared with a novel alcohol/salt ATPE, polymer/polymer, polymer/salt and surfactant ATPE systems have some disadvantage such as the high cost and viscosity as well as slow segregation. There are difficulties in isolating the extracted molecules from the polymer phase or micellar phase by re-extraction and environmental pollution resulting from the recycling of phase-forming polymers $[68,76]$.

\section{Conclusion}

The ATPE is the suitable technique for separation and purification of bioproducts in biological and biotechnological fields, especially the PEG/salts system. However, the implementation of the PEG/salt in the large scale may cause environmental problems due to the great amount of chemicals (salts and polymers) needed to phase forming and the high cost resulting from effectively recycling. To overcome it, some modifications are introduced into the system to purify good quality of biomolecules with low-cost and safely to the environment. This modification includes synthesized polymers $\left(\mathrm{P}_{\mathrm{NBAC}}, \mathrm{P}_{\mathrm{ADBA}}\right)$, copolymers $\left(\mathrm{P}_{\mathrm{NDBC}}, \mathrm{P}_{\mathrm{ABC}}\right)$, reverse micelle solvent ATPS system and interaction of HPLC with the system to increase the extraction rate. Furthermore, the application of a continuous ATPE system is an alternative technique for the recovery of proteins in large scale. This, in fact, provides the ability to recover proteins in higher efficiencies, increases partition coefficients and shortens processing time. Therefore, the continuous separation ATPE system can be used in pharmaceuticals, foods and chemical industries for purification of high-value bioproducts.

Although the ATPE has been extensively used for recovering of biomolecules, the poor understanding of mechanism that governs phase formation and solute partitioning in the ATPE hinders its application in some cases. Therefore, using of the ATPS with some modifications, such as affinity ligands, a substitute of polymers or using copolymers and a combination of the ATPS with other methods (e.g. chromatography), are more effective due to the high efficiency of separation, purification and increasing recovery yields of bioproducts.

\section{Acknowledgement}

The authors would like to thank the financial support from the Fundamental Research Funds for the Central Universities (Project 2013PY096), the Ministry of Scientific and Technology China (Grant No. 2012BAD28B06) and National Natural Science Foundation, China (Grant No. 31172294).

\section{References}

1. Alberttson PA (1986) Partition of Cell Particles and Macromolecules. Separation and Purification of biomolecules, cell organelles, membranes and cells in aqueous polymer two-phase systems and their use in biochemical analysis and biotechnology. Wiley-Interscience, New York.

2. Zaslavsky BY (1994) Aqueous Two-phase Partitioning, Physical Chemistry and Bioanalytical Applications. Marcel Dekker Inc, New York.

3. Truust H, G Johansson (1998) Fractionation of Wheat Gliadins by CounterCurrent Distribution using an Organic Two-Phase System. J Chromatogr B 711: 245-254

4. Hatti-Kaul R (2000) Aqueous Two-Phase Systems: Methods and Protocols. Humana Press 11

5. Gu Z, CE Glatz (2007) Aqueous Two-Phase Extraction for Protein Recovery from Corn Extracts. J Chromatogr B 845: 38-50.

6. Alcantara LAP, Minim LA, Minim VPR, Bonomo RCF, da Silv LHM, et al. (2011) Application of the Response Surface Methodology for Optimization of Whey Protein Partitioning in PEG/Phosphate Aqueous Two-Phase System. J Chromatogr B 879: 1881-1885.

7. Salabat A, Sadeghi R, Moghadam ST, Jamehbozorg B (2011) Partitioning of
I-methionine in aqueous two-phase systems containing poly (propylene glycol) and sodium phosphate salts. J Chem Thermody 43: 1525-1529.

8. Liu Y, Wu Z, Zhang Y, Yuan H (2012) Partitioning of Biomolecules in Aqueous Two-Phase Systems of Polyethylene Glycol and Nonionic Surfactant. Biochem Eng J 69: 93-99.

9. Biazus JPM, Santana JCC, Souza RR, Jordao E, Tambourgi EB (2007) Continuous Extraction of A-And B-Amylases from Zea Mays Malt in APEG4000/ Cacl2 ATPS. J Chromatogr B 858: 227-233.

10. Ling Y, Nie HL, Su SN, Branford-White C, Zhu L (2010) Optimization of Affinity Partitioning Conditions of Papain in Aqueous Two-Phase System using Response Surface Methodology. Sep Purif Technol 73: 343-348.

11. Yucekan I, S Onal (2011) Partitioning of Invertase from Tomato in Poly (Ethylene Glycol)/Sodium Sulfate Aqueous Two-Phase Systems. Process Biochem 46: 226-232.

12. Mehrnoush A, Mustafa S, Sarker MI, Yazid AMM (2012) Optimization of Serine Protease Purification from Mango (Mangifera Indica cv. Chokanan) Peel in Polyethylene Glycol/Dextran Aqueous Two Phase System. Int J Mol Sci 13 3636-3649.

13. Bhavsar K, V Ravi Kumar, J Khire (2012) Downstream Processing of Extracellular Phytase from Aspergillus Niger: Chromatography Process Vs. Aqueous Two Phase Extraction for its Simultaneous Partitioning and Purification. Process Biochem 47: 1066-1072.

14. Zhou Y, Hu C, Wang N, Zhang W, Yu X (2013) Purification of Porcine Pancreatic Lipase by Aqueous Two-Phase Systems of Polyethylene Glycol and Potassium Phosphate. J Chromatogr B 926: 77- 82.

15. Rosa PAJ, Azevedo AM, Sommerfeld S, Mutter A, Aires-Barros MR, et al. (2009) Application of Aqueous Two-Phase Systems to Antibody Purification: a Multi Stage Approach. J Biotechnol 139: 306-313.

16. Rosa PAJ, Azevedo AM, Sommerfeld S, Bäcker W, Aires-Barros MR (2011) Aqueous Two-Phase Extraction as a Platform in the Biomanufacturing Industry: Economical and Environmental Sustainability. Biotechnol Adv 29: 559-567.

17. Rosa PAJ, Azevedo AM, Sommerfeld S, Mutter M, Bäcker W, et al. (2012) Continuous Aqueous Two-Phase Extraction of Human Antibodies using a Packed Column. J Chromatogr B 880: 148-156.

18. Brooks DE, Fisher D (1985) Partitioning in aqueous two-phase systems. Academic Press.

19. Brooks E, Sharp KA, Fischer D (1985) Partitioning in Aqueous Two-Phase Systems: Theory, Methods, Uses and Applications to Biotechnology. Academic Press.

20. Asenjo JA, BA Andrews (2012) Aqueous Two-Phase Systems for Protein Separation: Phase Separation and Applications. J Chromatogr A 1238: 1-10.

21. Rosa PAJ, Ferreira IF, Azevedo AM, Aires-Barros MR (2010) Aqueous TwoPhase Systems: A Viable Platform in the Manufacturing of Biopharmaceuticals. J Chromatogr A 1217: 2296-2305.

22. Raghavarao KSMS, Rastogi NK, Gowthaman MK, Karanth NG (1995) Aqueous Two-Phase Extraction for Downstream Processing of Enzymes/Proteins. Adv Appl Microbol 41: 97-171.

23. Nitsawang S, R Hatti-Kaul, P Kanasawud (2006) Purification of Papain from Carica Papaya Latex: Aqueous Two-Phase Extraction versus Two-Step Salt Precipitation. Enzyme Microb Tech 39: 1103-1107.

24. do Nascimento ISB, Coimbra JSR, Martins JP, Silva LHM, Bonomo RCF, et al. (2010) Partitioning of Glutenin Flour of Special Wheat using Aqueous TwoPhase Systems. J Cereal Sci 52: 270-274

25. Ibarra-Herrera CC, O Aguilar, M Rito-Palomares (2011) Application of an Aqueous Two-Phase Systems Strategy for the Potential Recovery of a Recombinant Protein from Alfalfa (Medicago Sativa). Sep Purif Technol 77: 94-98.

26. Yin L, Sun CK, Han X, Xu L, Xu Y, et al. (2011) Preparative Purification of Bromelain (EC 3.4. 22.33) from Pineapple Fruit by High-Speed CounterCurrent Chromatography using a Reverse-Micelle Solvent System. Food Chem 129: 925-932.

27. Junwei Z, Yan W, Qijun P (2013) Extraction of Theanine from Waste Liquid of Tea Polyphenol Production in Aqueous Two-Phase Systems with Cationic and Anionic Surfactants. Chinese J Chem Eng 21: 31-36.

28. Zhang D, Zu Y, Fu Y, Wang W, Zhang L, et al. (2012) Aqueous Two-Phase 
Citation: Goja AM, Yang H, Cui M, Li C (2013) Aqueous Two-Phase Extraction Advances for Bioseparation. J Bioprocess Biotech 4: 140 doi: 10.4172/2155-9821.1000140

Page 7 of 8

Extraction and Enrichment of Two Main Flavonoids from Pigeon Pea Roots and the Antioxidant Activity. Sep Purif Technol 102: 26-33.

29. Dong Y, Zhang F, Wang Z, Du L, Hao A, et al. (2012) Extraction and Purification of Recombinant Human Serum Albumin from Pichia Pastoris Broths using Aqueous Two-Phase System Combined with Hydrophobic Interaction Chromatography. J Chromatogr A 1245: 143-149.

30. Priyanka BS, Rastogi NK, Raghavarao KSMS, Thakur MS (2012) Downstream Processing of Luciferase from Fireflies (Photinus Pyralis) using Aqueous TwoPhase Extraction. Process Biochem 47: 1358-1363.

31. Wu Q, Lin DQ, Yao SJ (2013) Evaluation of Poly (Ethylene Glycol)/ Hydroxypropyl Starch Aqueous Two-Phase System for Immunoglobulin G Extraction. J Chromatogr B 928: 106-112.

32. Antov MG, DM Peričin, MG Dašić (2006) Aqueous Two-Phase Partitioning of Xylanase Produced by Solid-State Cultivation of Polyporus Squamosus. Process Biochem 41: 232-235.

33. Su CK, Chiang BH (2006) Partitioning and Purification of Lysozyme from Chicken Egg White using Aqueous Two-Phase System. Process Biochem 41: 257-263

34. Zhao XY, Qu F, Dong M, Chen F, Luo AQ, et al. (2012) Separation of Proteins by Aqueous Two-Phase Extraction System Combined with Liquid Chromatography. Chinese J Anal Chem 40: 38-42.

35. Gai Q, Qu F, Zhang T, Zhang Y (2011) Integration of carboxyl modified magnetic particles and aqueous two-phase extraction for selective separation of proteins. Talanta 85: 304-309.

36. Srinivas N, A Narayan, K Raghavarao (2002) Mass Transfer in a Spray Column during Two-Phase Extraction of Horseradish Peroxidase. Process Biochem 38 : 387-391.

37. Saravanan S, Rao JR, Nair BU, Ramasami T (2008) Aqueous Two-Phase Poly (Ethylene Glycol)-Poly (Acrylic Acid) System for Protein Partitioning: Influence of Molecular Weight, Ph and Temperature. Process Biochem 43: 905-911.

38. Raja S, Murty VR, Thivaharan V, Rajasekar V, Ramesh V (2011) Aqueous Two Phase Systems for the Recovery of Biomolecules-A Review. Sci Tech 1: 7-16.

39. Ferreira GB, Evangelista AF, Junio JBS, de Souza RR, Santana JCC, et al. (2007) Partitioning Optimization of Proteins from Zea Mays Malt in ATPS PEG 6000/Cacl2. Braz Arch Biol Techn 50: 557-564

40. Ooi CW, Tey BT, Hii SL, Kamal SMM, Lan JCW, et al. (2009) Purification of Lipase Derived from Burkholderia Pseudomallei with Alcohol/Salt-Based Aqueous Two-Phase Systems. Process Biochem 44: 1083-1087.

41. Rao JR, Nair BU (2011) Novel Approach Towards Recovery of Glycosaminoglycans from Tannery Wastewater. Bioresource Technol 102: 872-878.

42. Montalvo-Hernández B, Rito-Palomares M, Benavides J (2012) Recovery of Crocins from Saffron Stigmas (Crocus Sativus) in Aqueous Two-Phase Systems. J Chromatogr A 1236: 7-15.

43. Cao Q, Li S, He C, Li F, Liu F (2007) Extraction and Determination of Papaverin in Pericarpium Papaveris Using Aqueous Two-Phase System of Poly (Ethylene Glycol) -(NH4)2SO4 Coupled with High-Performance Liquid Chromatography. Analytica Chimica Acta 590: 187-194.

44. Pei Y, Wang J, Wu K, Xuan X, Lu X (2009) Ionic Liquid-Based Aqueous TwoPhase Extraction of Selected Proteins. Sep Purif Technol 64: 288-295.

45. Pietruszka N, Galaev IY, Kumar A, Brzozowski ZK, Mattiasson B (2000) New Polymers Forming Aqueous Two-Phase Polymer Systems. Biotechnol Progr 16: 408-415.

46. Boeris V, Spelzini D, Farruggia B, Pico G (2009) Aqueous Two-Phase Extraction and Polyelectrolyte Precipitation Combination: A Simple and Economically Technologies for Pepsin Isolation from Bovine Abomasum Homogenate. Process Biochem 44: 1260-1264.

47. Hustedt H, Kroner KH, Papamichale N (1988) Continuous Cross-Current Aqueous Two Phase Extraction of Enzymes from Biomass. Process Biochem 23: $129-137$.

48. Schmidt AS, Ventom AM, Asenjo JA (1994) Partitioning and Purification of A-Amylase in Aqueous Two-Phase Systems. Enzyme Microb Tech 16: 131-142.

49. Lin Q, Mie HL, You TW, Shan JY, Zhu Q (2003) Modeling the Protein Partitioning in Aqueous Polymer Two-Phase Systems: Influence of Polymer Concentration and Molecular Weight. Chem Eng Sci 58: 2963-2972.
50. Marini A, Imelio N, Picó G, Romanini D, Farruggia B (2011) Isolation of a Aspergillus Niger Lipase from a Solid Culture Medium with Aqueous TwoPhase Systems. J Chromatogr B 879: 2135-2141.

51. Mattiasson B, Kaul R (1986) Use of Aqueous Two-Phase Systems for Recovery and Purification in Biotechnology. Separation, Recovery, and Purification and Biotechnology 7: 78-92

52. Ashipala OK, He Q (2008) Optimization of Fibrinolytic Enzyme Production by Bacillus Subtilis DC-2 in Aqueous Two-Phase System (Poly-Ethylene Glycol 4000 And Sodium Sulfate). Bioresource Technol 99: 4112-4119.

53. Hemavathi AB, Raghavarao KSMS (2011) Differential Partitioning of B-Galactosidase and B-Glucosidase using Aqueous Two Phase Extraction. Process Biochem 46: 649-655.

54. Karkas T, Önal S (2012) Characteristics of Invertase Partitioned in Poly (Ethylene Glycol)/Magnesium Sulfate Aqueous Two-Phase System. Biochem Eng J 60: 142-150.

55. Ribeiro MZ, Silva DP, Vitolo M, Roberto IC, Pessoa-Jr A (2007) Partia Purification of Glucose-6-Phosphate Dehydrogenase by Aqueous Two-Phase Poly (Ethyleneglycol)/Phosphate Systems. Braz J Microb 38: 78-83.

56. Mohamadi H, Omidinia E, Dinarvand R (2007) Evaluation of Recombinan Phenylalanine Dehydrogenase Behavior in Aqueous Two-Phase Partitioning Process Biochem 42: 1296-1301.

57. Pico G, Romanini D, Nerli B, Farruggia B (2006) Polyethyleneglycol Molecular Mass and Polydispersivity Effect on Protein Partitioning in Aqueous Two-Phase Systems. J Chromatogr B 830: 286-292.

58. Yue $H$, Yuan Q, Wang W (2007) Purification of Phenylalanine Ammonialyase in PEG 1000/ Na2SO4 Aqueous Two-Phase System by a Two-Step Extraction. Biochem Eng J 37: 231-237.

59. Mehrnoush A, Mustafa S, Yazid AMM (2011) 'Heat-Treatment Aqueous Two Phase System' for Purification of Serine Protease from Kesinai (Streblus Asper) Leaves. Molecules 16: 10202-10213.

60. Bora MM, Borthakur S, Rao PC, Dutta NN (2005) Aqueous Two-Phase Partitioning of Cephalosporin Antibiotics: Effect of Solute Chemical Nature. Sep Purif Technol 45: 153-156.

61. Tomatani EJ, Vitolo M (2007) Production of High-Fructose Syrup using Immobilized Invertase in a Membrane Reactor. J Food Eng 80: 662-667.

62. Yang L, Huo D, Hou C, He K, Lv F, et al. (2010) Purification of Plant-Esterase in PEG1000/Nah2po4 Aqueous Two-Phase System by a Two-Step Extraction. Process Biochem 45: 1664-1671.

63. Barbosa JMP, Souza RL, Fricks AT, Zanin GM, Soares CMF, et al. (2011) Purification of Lipase Produced by a New Source of Bacillus in Submerged Fermentation using an Aqueous Two-Phase System. J Chromatogr B 879: 3853-3858.

64. Franco TT, Andrews AT, Asenjo JA (1996) Conservative Chemical Modification of Proteins to Study the Effects of a Single Protein Property on Partitioning in Aqueous Two-Phase Systems. Biotechnol Bioeng 49: 290-299.

65. Benavides J, Rito-Palomares M (2008) Practical Experiences from the Development of Aqueous Two-Phase Processes for the Recovery of High Value Biological Products. J Chem Technol Biot 83: 133-142.

66. Roe S (2000) Protein Purification Techniques: A Practical Approach. Oxford University Press.

67. Anandharamakrishnan C, Raghavendra SN, Barhate RS, Hanumesh $U$ Raghavarao KSMS (2005) Aqueous Two-Phase Extraction for Recovery of Proteins from Cheese Whey. Food Bioprod Process 83: 191-197.

68. Li X, Wan J, Cao X (2010) Preliminary Application of Light-Ph Sensitive Recycling Aqueous Two-Phase Systems to Purification of Lipase. Process Biochem 45: 598-601.

69. Chen X, Xu G, Li X, Li Z, Ying H (2008) Purification of an A-Amylase Inhibitor in a Polyethylene Glycol/Fructose-1, 6-Bisphosphate Trisodium Salt Aqueous Two-Phase System. Process Biochem 43: 765-768.

70. Zhang Y Liu J (2010) Purification and InSitu Immobilization of Lipase From of a Mutant of Trichosporon Laibacchiiusing Aqueous Two-Phase Systems. J Chromatogr B 878: 909-912.

71. Ketnawa S, Sai Ut S, Theppakorn T, Chaiwut P, Rawdkuen S (2009) Partitioning of Bromelain from Pineapple Peel (Nang Lae Cultv.) by Aqueous Two Phase System. Asian J Food Agro-Indus 2: 457-468. 
Citation: Goja AM, Yang H, Cui M, Li C (2013) Aqueous Two-Phase Extraction Advances for Bioseparation. J Bioprocess Biotech 4: 140 doi: 10.4172/2155-9821.1000140

Page 8 of 8

72. da Silva ME, Franco TT (2000) Purification of Soybean Peroxidase (Glycine Max) by Metal Affinity Partitioning in Aqueous Two-Phase Systems. J Chromatogr B 743: 287-294.

73. Hachem F, Andrews BA, Asenjo JA (1996) Hydrophobic Partitioning of Proteins in Aqueous Two-Phase Systems. Enzyme Microb Tech 19: 507-517.

74. Tubio G, Nerli B, Pico G (2004) Relationship between the Protein Surface Hydrophobicity and its Partitioning Behaviour in Aqueous Two-Phase Systems of Polyethyleneglycol-Dextran. J Chromatogr B 799: 293-301.

75. Diamond AD, Hsu JT (1990) Protein Partitioning in PEG/Dextran Aqueous TwoPhase Systems. AIChE J 36: 1017-1024.

76. Tan ZJ, Li FF, Xu XL (2013) Extraction and Purification of Anthraquinones Derivatives from Aloe Vera L. using Alcohol/Salt Aqueous Two-Phase System. Bioprocess Biosys Eng 36: 1105-1113.

77. Hu R, Feng X, Chen P, Fu M, Chen H, et al., (2011) Rapid, Highly Efficient Extraction and Purification of Membrane Proteins using a Microfluidic Continuous-Flow Based Aqueous Two-Phase System. J Chromatogr A 1218: 171-177.

78. Rito-Palomares M (2004) Practical Application of Aqueous Two-Phase Partition to Process Development for the Recovery of Biological Products. J Chromatogr B 807: 3-11.

79. Giuliano KA (1991) Aqueous Two-Phase Protein Partitioning using Textile Dyes as Affinity Ligands. Anal Biochem 197: 333-339.

80. Teotia S, Lata R, Gupta MN (2001) Free Polymeric Bioligands in Aqueous Two-Phase Affinity Extractions of Microbial Xylanases and Pullulanase. Protein Expres Purif 22: 484-488.

81. Xu Y, Vitolo M, Albuquerque CN, Pessoa JrA (2002) Affinity Partitioning of Glucose-6-Phosphate Dehydrogenase and Hexokinase in Aqueous TwoPhase Systems with Free Triazine Dye Ligands. J Chromatogr B 780: 53-60.

82. Silva DF, Azevedo AM, Fernandes P, Chu V, Conde JP, et al., (2012) Design of a Microfluidic Platform for Monoclonal Antibody Extraction using an Aqueous Two-Phase System. J Chromatogr A 1249: 1-7.

83. Zhi W, Deng Q (2006) Purification of Salvianolic Acid B from the Crude Extract of Salvia Miltiorrhiza with Hydrophilic Organic/Salt-Containing Aqueous TwoPhase System by Counter-Current Chromatography. J Chromatogr A 1116: 149-152.

84. Wang H, Dong Y, Xiu ZL (2008) Microwave-Assisted Aqueous Two-Phase Extraction of Piceid, Resveratrol and Emodin from Polygonum Cuspidatum by Ethanol/Ammonium Sulphate Systems. Biotechnol Lett 30: 2079-2084.

85. Jiang B, Li ZG, Dai JY, Zhang DJ, Xiu ZL (2009) Aqueous Two-Phase Extraction of 2, 3-Butanediol from Fermentation Broths using an Ethanol/Phosphate System. Process Biochem 44: 112-117.
86. Louwrier A (1998) Model Phase Separations of Proteins using Aqueous/Ethanol Components. Biotechnol Tech 12: 363-365.

87. Wang W, Wan J, Ning B, Xia J, Cao X (2008) Preparation of a Novel LightSensitive Copolymer and its Application in Recycling Aqueous Two-Phase Systems. J Chromatogr A 1205: 171-176.

88. Kong FQ, Cao XJ, Xia JA, Hour B (2007) Synthesis and Application of a LightSensitive Polymer Forming Aqueous Two-Phase Systems. J Ind Eng Chem 13: $424-428$

89. Chen JP, Miao S, Wan JF, Xia JA, Cao XJ (2010) Synthesis and Application of Two Light-Sensitive Copolymers Forming Recyclable Aqueous Two-Phase Systems. Process Biochem 45: 1928-1936.

90. Ning B, Wan JF, Cao XC (2009) Preparation and Recycling of Aqueous TwoPhase Systems with Ph-Sensitive Amphiphilic Terpolymer PADB. Biotechnol Progr 25: 820-824.

91. Miao S, Chen JP, Cao XJ (2010) Preparation of a Novel Thermo-Sensitive Copolymer Forming Recyclable Aqueous Two-Phase Systems and its Application in Bioconversion of Penicillin G. Sep Purif Technol 75: 156-164.

92. Yan B, Cao X (2012) Preparation of Aqueous Two-Phase Systems Composed of Two Ph-Response Polymers and Liquid-Liquid Extraction of Demeclocycline. J Chromatogr A 1245: 39-45

93. Xing J, Li F (2009) Separation and Purification of Aloe Polysaccharides by a Combination of Membrane Ultrafiltration and Aqueous Two-Phase Extraction. Appl Biochem Biotech 158: 11-19.

94. Dong XY, Meng Y, Feng XD, Sun Y (2010) A Metal-Chelate Affinity Reverse Micellar System for Protein Extraction. Biotechnol Progr 26: 150-158.

95. Osakai T, Shinohara A (2008) Electrochemical Aspects of the Reverse Micelle Extraction of Proteins. Anal Sci 24: 901-906.

96. Fileti AMF, Fischer GA, Tambourgi EB (2010) Neural Modeling of Bromelain Extraction by Reversed Micelles. Braz Arch Biol Technol 53: 455-463.

97. Vazquez-Villegas P, Espitia-Saloma E, Rito-Palomares M, Aguilar O (2013) Low-Abundant Protein Extraction from Complex Protein Sample using a Novel Continuous Aqueous Two-Phase Systems Device. J Separ Sci 36: 391-399.

98. Rosa PAJ, Azevedo AM, Sommerfeld S, Mutter M, Bäcker W, et al., (2012) Continuous Purification of Antibodies from Cell Culture Supernatant with Aqueous Two-Phase Systems: From Concept to Process. Biotechnol J 8: 352362

99. González-González M, Mayolo-Deloisa K, Rito-Palomares M, Winkler R (2011) Colorimetric Protein Quantification in Aqueous Two-Phase Systems. Process Biochem 46: 413-417. 